\title{
Financial leverage and financial market instability: the case of Latvia
}

\begin{abstract}
The present paper is an attempt to integrate financial market instability and corporate finance in a dynamic setup. The results of the study highlight that financial market instability, tangibility, and profitability have a negative impact on leverage of the firm, whereas assets growth has a positive effect.
\end{abstract}

Keywords: capital structure, financial leverage, financial stress index, financial market instability.

Šiuo straipsniu siekiama dinamine sąranka sujungti finansų rinkų nestabilumą ir ịmonių finansus. Tyrimo rezultatai parodè, kad finansų rinkos nestabilumas, materialumas ir pelningumas turi neigiamą poveikị ịmonès finansiniam svertui, o turto augimas turi teigiamą poveiki.

Raktiniai žodžiai: kapitalo struktūra, finansinis svertas, finansinès sistemos streso indeksai, finansų rinkos nestabilumas.

JEL Classifications: G32/O16.

\section{Introduction}

The choice of the measure of dynamics of capital structure may be controversial, as the lack of a univocal definition of capital structure led to emergence of a variety of factors used to measure it. Usually, different forms of debt ratio are used. According to A. A. Bevan and J. Danbolt (2002), focusing on long-term debt when analyzing firms which incorporate a larger percentage of short-term debt into their structure, will yield limited explanatory power. They argue that inclusion of trade credit has a substantial impact on explanatory variables. Thus, in the case of Latvia, where short-term liabilities (mainly trade credits) play an important role in corporate financing, application of the broader measure of capital structure is reasonable. Second important question is the use of book or market values in their capital structure measures. Market values result from capital structure theory, but in practice, there is a problem with obtaining data on the market value of corporate debt. According to J. R. Graham and C. Harvey (2001), application of book values is reasonable because financial managers use mainly book values in decision making. Some researchers use market and book values of debt ratios at the same time, obtaining similar results for

Ramona RUPEIKA-APOGA - Dr. oec, University of Latvia. Address: Aspazijas 5, Riga, Latvia; phone: 00371 67034625; e-mail: rr@lu.lv.

Elvira ZELGALVE - Dr. oec, University of Latvia. Address: Aspazijas 5, Riga, Latvia; phone: 00371 67034620; e-mail: elzelg@lu.lv. 
both measures (e.g., MacKay and Philips, 2005).

In line with the above argumentation, the measure of corporate leverage used in this study is total liabilities over equity, calculated with book values.

The same is true for the choice of the measure of financial market instability determinants. In this study the financial market instability is characterized by financial stress (e.g., Hakkio and Keeton, 2009), using the Latvian financial stress index and individual components of the index.

The object of this paper is the behaviour of capital structure of non-financial companies.

The purpose of this research is to identify and to analyse the main determinants affecting financial leverage of Latvian nonfinancial companies taking into account financial market instability.

To achieve our purpose the following tasks were conducted:

- to identify the main capital structure theories;

- to identify and to analyse the main determinants effecting financial leverage, with an emphasis on the instability of financial markets;

- to offer the model that combines financial market instability with corporate finance in Latvia;

- to make conclusions and to put forward recommendations about financial market instability and corporate finance correlation on the basis of the authors' findings.

The research methods used in this paper start with a literature review in order to highlight the difficulties faced by companies in choosing the optimal capital structure. During the development of the paper appropriate econometric technique, Generalized Methods of Moments (GMM) was used to capture the behaviour of capital structure of non-financial firms from 1995 to 2012. The choice of using data starting in the year 1995 can be discussed. Normally, longer time series entail more data points and thus better statistical properties. The choice of time period usually is based on two factors: access to data and relevance of accessible data. Taking into account that Latvia regained its independence only in the 90s of the 20-th century and was under transition process for some years the period from 1995 to 2012 fully responds to the mentioned requirements. Additionally, this period includes all financial crises: starting with first local banking crisis in 1995, Russian crisis in 1998, last global financial crisis from 2008-2009 and local banking crisis in 2011.

The analysis conducted in this paper is based on data and statistics provided mainly by Central Statistical Bureau of Latvia, Financial and Capital Market Commission, Ministry of the Finance of the Republic of Latvia, Bank of Latvia, by certain empirical studies and by Eurostat.

\section{Literature review}

There are various theories that help companies to understand how to build their capital structure, but nevertheless, the optimal capital structure is still the subject of intense debate. Taking into account that in recent years the economic environment has changed globally, and thus, creating new challenges for companies, rational resource structure formation becomes particularly challenging. The major capital structure decision factors are known, but the complexity remains largely unresolved.

Since the publication of the F. Modigliani and M. H. Miller's (1958) “irrelevance 
theory of capital structure", the theory of corporate capital structure has been a study of interest to researchers. The first two primary competing theories of financing decisions are the static trade-off theory and the pecking order theory, however, the market timing theory has increasingly challenged both of the above theories.

F. Modigliani and M. H. Miller (1958) start by assuming that the firm has a particular set of expected cash flows. When the firm chooses a certain proportion of debt and equity to finance its assets, all that it does is to divide up the cash flows among investors. Investors and firms are assumed to have equal access to financial markets, which allows for homemade leverage. The investor can create any leverage that was wanted but not offered, or the investor can get rid of any leverage that the firm took on but was not wanted. As a result, the leverage of the firm has no effect on the market value of the firm.

The term trade-off theory is used to describe several related theories. In all of these theories, a decision maker running a firm evaluates the various costs and benefits of alternative leverage plans. The trade-off theory (Myers, 1977) indicates that firms have a target debt ratio determined by balancing the cost and benefits of debt versus equity. The trade-off theory assumes that firms trade off the benefits and costs of debt and equity financing and find an "optimal" capital structure after accounting for market imperfections such as taxes, bankruptcy costs and agency costs. Often it is assumed that an interior solution is obtained so that marginal costs and marginal benefits are balanced.

The pecking order theory describes that a firm prefers internal to external financing, and retained earnings are a priority source of funds and debt is a better deal than equity financing (Myers, 1984, Myers and Majluf, 1984). If internal funds are not enough to finance investment opportunities, firms may or may not acquire external financing, and if they do, they will choose among the different external finance sources in such a way as to minimise additional costs of asymmetric information.

Empirical tests to proof whether the pecking order or the trade-off theory is a better predictor of observed capital structures find support for both theories of capital structure (Shyam-Sunder and Myers, 1999; Fama and French, 2002).

Market timing theory approach says that there is not any relationship between capital structure and cost of capital. There will not effect of increasing debt on cost of capital. M. Baker and J. Wurgler (2002) first examine the market timing theory and report that an external finance-weighted average of the historical market-to-book ratio is negatively related to current leverage through net equity issues. Value of firm and cost of capital is fully affected from investor's expectations. Investors' expectations may be further affected by large numbers of other factors which have been ignored by traditional theorem of capital structure.

The recent economic crisis has emphasized the need for efficient financial markets. Efficient financial markets that are sound and well-functioning play a vital role in the development of the country. A characteristic of efficient financial market is that it channels funds from the ultimate lenders to the ultimate borrowers in a way that the funds are used in the most socially useful manner. Shocks to the system, which affect the functioning of some part of it, may ultimately cause large costs to society. However, it is often difficult to determine how smoothly the financial system is 
functioning. One reason is that there are several sub-markets, which can develop in different directions. This makes it difficult to assess the functioning of the system as a whole. One way of forming an overall impression of whether there are disruptions on markets is to use the index for financial stress. Financial market instability can be characterized by financial stress (Hakkio and Keeton, 2009). Many economists support three most important indications of elevated financial stress: uncertainty, large expected financial losses and increased risk aversion on the behalf of the financial system players (e.g., Illing and Liu, 2003, 2006; Misina and Tkacz, 2009; Hakkio and Keeton, 2009).

The evidence presented in the paper „Corporate Leverage, the Cost of Capital, and the Financial Crisis in Latin America" (e.g., Bebczuk and Galindo, 2010) suggests that the crisis in 2008-2009 did not have a significant impact on Latin American corporations. In fact, the authors found that if anything, during the crisis period, corporate leverage increased for the large, listed firms after controlling for micro fundamentals. This is consistent with the view that during the crisis capital is reallocated from smaller and riskier firms to larger ones. The authors proved that leverage of large firms in Latin American countries depends positively on the firm's size and its tangibility, and negatively with respect to profitability, as predicted by the asymmetric information approach to corporate finance.

In accordance with A. E. Bernardo and I. Welch (2012), first, when deciding on leverage, each firm takes into account that any weakening in asset value fundamentals will have more severe repercussions if, on aggregate, the financial sector is more levered. Second, if fundamentals deteriorate, each levered firm takes into account that the asset price will be higher if fewer of its peers are selling pre-emptively. If this is the case, every firm realizes that it can get a higher price by immediately selling its own assets pre-emptively. Third, leverage also has an impact on pre-emptive selling. If the rest of the financial sector is conservatively financed, individual firms know that fewer of its peers will be forced to liquidate and they can take more of a chance in holding onto their own risky assets, because they will be less concerned about selling behind other firms. Conversely, when the rest of the financial sector is not well capitalized, more firms will scramble early to divest their risky assets. Some regulatory proposals under consideration would impose higher capital constraints on only some financial institutions. Their analysis suggests that this would encourage other firms, not subject to these constraints, to take on more leverage.

\section{Determinants choice: dependent and independent variables}

\section{Dependent Variable}

The dependent variable in the current study is the financial leverage. The leverage ratio is used to calculate the financial leverage of a company; it reflects the company's financing methods and the company's ability to meet its financial obligations. There are a number of different ratios, but the main determinants are debt, equity, assets, operating income and interest expenses (e.g., Lee, Koh, Kyung Ho, 2011). The most well known financial leverage ratio is the debt-to-equity ratio $(D / E)$, 
which indicates how much the company depends on debt financing. Usually, a typical D/E ratio is $2: 1$, with only one-third of the debt in the long-term. A high $\mathrm{D} / \mathrm{E}$ ratio means possible difficulties in repaying interest and capital payments, while obtaining additional resources.

Current study measures leverage (Lev) by the debt-to-equity ratio. Leverage is calculated as the ratio of total liabilities to equity, as in Latvia, companies are equally financed through short- and long-term debts as the average size of the firms is small; thus company access to the equity market is rather problematic.

\section{Independent variables}

Lagged Leverage. The relationship between leverage and lagged leverage suggests costs of adjustment for capital structure, the lower this coefficient the higher the speed of adjustment (e.g., Ozkan, 2001; Gaud et al., 2005), whereas the higher coefficient the higher the costs of adjustments of the capital structure, as a result delaying the adjustment process.

Tangibility of Assets. The second main factor of this study is Tangibility of Assets as measured by fixed assets divided by total assets. Assets that are tangible are more desirable from the point of view of creditors because they are easier to repossess during bankruptcy.

Starting with S. Titman and R. Wessels (1988), capital structure studies have consistently controlled for the effect of an aggregate measure of tangible assets on leverage. Many of these studies have proved that tangibility and leverage are positively related (e.g., Rajan and Zingales, 1995; MacKay and Phillips, 2005; Bharath, Pasquariello and $\mathrm{Wu}, 2007$; Faulkender and Petersen, 2006; Wald and Long, 2007;
Kale and Shahrur, 2007; Lemmon, Roberts and Zender, 2008; Lemmon and Zender 2008). This is largely explained by the fact that tangible assets can be pledged as collateral to lenders and thus allow companies to raise debt. At the same time other authors (e.g., Williamson, 1988; Shleifer and Vishny, 1992; Hart and Moore, 1994; Rajan and Zingales, 1995 and Campello and Giambona, 2010) place doubt on the existing positive correlation unambiguousness.

As previously discussed, it is possible that positive, as well as negative relationship exists between financial leverage (Lev) and tangibility (TNGB), therefore the current study does not support a particular position.

Hypothesis 1: Tangibility of Assets has a strong relationship (positive or negative) with leverage.

Profitability. The majority of empirical evidence favours the view that profitability is negatively correlated with leverage, supporting the Pecking-Order Hypothesis. It is considered that profitable companies have larger amounts of retained earnings thus they can afford to finance their needs internally. According to Pecking-Order Hypothesis, firms use internally generated funds, then debt, and as a last resort turn to equity market for their financing needs (e.g. Myers, 1984; Titman and Wessels, 1988; Friend and Lang, 1988; Rajan and Zingales,1995; Campbell and Jerzemowska, 2001; Bevan and Danbolt, 2002; Gajdka, 2002).

Profitability is calculated as the ratio of earnings before tax to total assets.

Hypothesis 2: Profitability has a negative relationship with leverage.

Earnings Volatility. Potential default risk related to high earnings volatility causes risk-averse managers to avoid excessive debt levels. The pecking-order theory 
predicts that firms with high volatility of financial results try to accumulate cash during good years to avoid underinvestment in the future. Highly volatile firms will have to pay high risk premiums to lenders. Earning volatility is, thus, expected to be negatively correlated with leverage. For example, C. Crutchley and R. Hansen (1989) found that greater earnings volatility leads to lower leverage. Both trade-off theory and the pecking-order theory suggest a negative relationship.

Earning volatility is calculated as the ratio of difference between earnings before tax in time $t$ and earnings before tax in time $\mathrm{t}-1$ to earnings before tax in time $\mathrm{t}-1$.

Hypothesis 3: Earnings Volatility has a negative relationship with leverage.

Growth opportunities. On the one hand, according to Pecking-Order theory, the relationship between growth and leverage is positive as growing firms have greater need for funds and, therefore, can be expected to borrow more (Campbell and Jerzemowska, 2001; Gajdka, 2002; Drobetz and Fix, 2003). On the other hand, empirical evidence in support of the negative relationship can be found in M. Jensen and W. Meckling (1976), S. Myers (1977), and R.Stulz (1990), S. Titman and R. Wesssels (1988), R. Rajan and L. Zingales (1995), and M. Barclay and C. Smith (1996).

As previously discussed, it is possible that there is a positive as well as negative relationship between financial leverage (Lev) and growth opportunities; therefore the current study does not support a particular position.

There are three determinants to measure growth opportunities: average growth rate of total assets, average growth rate of revenues from sales, and long-term investment to total assets. In this paper, 2 growth determinants were calculated: first, the growth of sales is calculated as yearly growth rate of revenues from sales, and second, growth of assets is calculated as growth of total assets (natural $\log$ of total assets).

Hypothesis 4: Growth opportunities have effect on leverage.

Financial market instability. In Latvia, the central Bank of Latvia calculates the Latvian financial stress index. Stress index is useful as a measure reflecting the summary evaluation of the condition of the financial system, a stress index can summarize the trends of many factors into a single easy-to-interpret and comparable measure of the condition of the financial system.

Table 1 features the variables included in the Latvian FSI (financial stress index) broken down by the respective groups of variables.

The values of variables marked by a "_" sign in the column "Impact" of Table 1 were multiplied by a coefficient $(-1)$ prior to aggregating, so that a positive value of those variables would signal a heightened stress period. Such a transformation means that, for example, positive growth of the credit institutions' loan portfolio would be interpreted as an indication of low stress and vice versa: the shrinking of the loan portfolio would be interpreted as an indication of heightened stress. In cases when the stress is being determined by changes in variables but not by their levels, logarithmic differences were calculated, which reflect the percentage changes in those variables.

The authors examine the impact of the Latvian financial stress index on the leverage, but in addition some of the index's components will be tested as well: provisioning ratio (special loan loss provisions for resident loans to resident loans ratio); interest rates on the interbank market 
Description of variables included in the FSI for Latvia

Table 1

\begin{tabular}{|c|c|c|c|c|}
\hline Group & Variable & Variable included in the FSI & $\begin{array}{l}\text { Transfor- } \\
\text { mation }\end{array}$ & Impact \\
\hline \multirow{5}{*}{$\begin{array}{l}\text { Balance sheet } \\
\text { indicators of } \\
\text { credit institutions }\end{array}$} & Profitability & ROA & & - \\
\hline & Provisioning ratio & $\begin{array}{l}\text { Special loan loss provisions for resident } \\
\text { loans to resident loans ratio }\end{array}$ & dlog & + \\
\hline & Loans granted & $\begin{array}{l}\text { Outstanding amount of } \\
\text { resident loans }\end{array}$ & dlog & - \\
\hline & Interbank lending & $\begin{array}{l}\text { Outstanding amount of liabilities to } \\
\text { resident MFIs }\end{array}$ & dlog & - \\
\hline & $\begin{array}{l}\text { Deposit } \\
\text { developments }\end{array}$ & $\begin{array}{l}\text { Outstanding amount of resident } \\
\text { deposits }\end{array}$ & dlog & - \\
\hline $\begin{array}{l}\text { Money market } \\
\text { indicators }\end{array}$ & $\begin{array}{l}\text { Interest rates on the } \\
\text { interbank market }\end{array}$ & $\begin{array}{l}\text { Spread between } 3 \text { month RIGIBOR and } \\
\text { EURIBOR }\end{array}$ & & + \\
\hline $\begin{array}{l}\text { Securities market } \\
\text { indicators }\end{array}$ & $\begin{array}{l}\text { Yield on government } \\
\text { debt securities }\end{array}$ & $\begin{array}{l}\text { Spread between the average yields on } \\
10 \text {-year Latvian and German govern- } \\
\text { ment bonds }\end{array}$ & & + \\
\hline
\end{tabular}

Source: N. Sinenko et al. (2012).

(spread between 3 month RIGIBOR and EURIBOR) and yield on government debt securities (spread between the average yields on 10-year Latvian and German government bonds and spread between the average yields on 10-year Latvian and EU government bonds). The movements of yield on government debt securities reflect the changes in the risk premium on investment in Latvian government debt instruments.

Additionally, the authors have chosen to use the 3 month TED spread as an indicator of stress on the money market. The TED spread is the difference between the interest rate on an unsecured interbank loan (RIGIBOR) and the interest rate on a treasury bill with the same maturity. The TED spread is an indicator of perceived credit risk in the general economy. This is because T-bills are considered risk-free while RIGIBOR reflects the credit risk of lending to commercial banks. When the TED spread increases that is a sign that lenders believe the risk of default on interbank loans is increasing. Interbank lenders, therefore, demand a higher rate of interest, or accept lower returns on safe investments such as T-bills. When the risk of bank defaults is considered to be decreasing, the TED spread decreases. Times of financial stress may be linked to increased credit and liquidity risks, at the same time as a flight-to-quality and a flight-to-liquidity arise. At such times RIGIBOR tends to rise, at the same time as the interest rate on treasury bills tends to fall. Both of these variables can in this way contribute to the TED spread increasing, which makes it a good indicator of periods of financial stress.

As a result following variables of financial market instability were chosen:

- FSI - Latvian financial stress index;

- TED spread - the difference between 3 months RIGIBOR and 3 months interest rate on a treasury bill;

- Interbank market spread - the difference between 3 month RIGIBOR and EURIBOR; 
- Provisioning ratio - special loan loss provisions for resident loans to resident loans ratio;

- Yield on government debt securities (De) - spread between the average yields on 10-year Latvian and German government bonds;

- Yield on government debt securities $(E U)$ - spread between the average yields on 10-year Latvian and EU government bonds.

During financial instability periods, firms with an ex-ante large portion of short-term debt relative to long-term debt, unable to roll-over their credit lines, should have been forced to reduce real assets by a larger amount (or to pay a higher interest rate) than otherwise similar firms, but less exposed to short-term debt. In Latvia, as was mentioned previously, companies are equally financed through short and long term debts.

Positive index values point to a stress level above the historical mean; therefore, the biggest the deviation of the variables from their historical means, the higher the stress level of the financial system (see figure 1). The period from 2004 to 2007 was marked by buoyant growth of the Latvian economy and banking sector, characterized by investment inflows, lending boom and a very low exposure to non-performing loans in the loan portfolios. Therefore, the stress index value was also lower than the long-term mean. Starting from the third quarter of 2008, the first signs of growing stress became apparent mainly as a result of the shrinking economic activity, drying-up lending and an ever accelerating fall in real estate prices. In the second half of the year, the financial stress deepened against the background of the collapse of Lehman Brothers and the subsequent liquidity squeeze and deterioration of the external economic environment. The stress level of the financial sector peaked at the end of 2008 with the take-over of JSC Parex banka and the government turning to international donors for assistance. The end of 2009 index indicates that the stress level has decreased significantly; therefore, the situation can be assumed to have been normalized: part of the variables characterising the financial

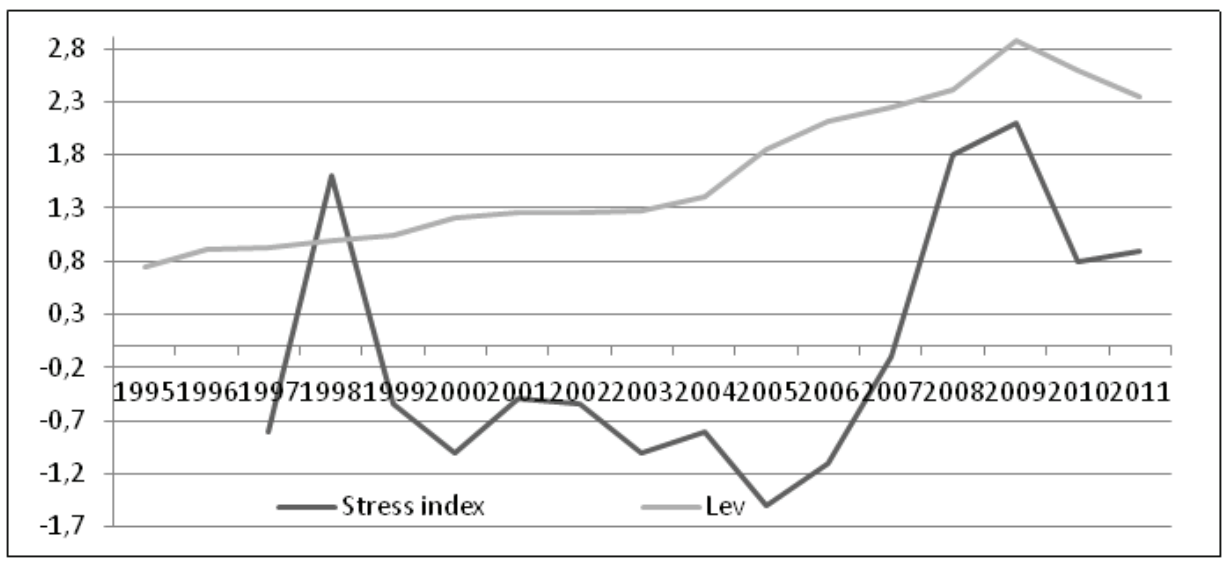

Fig. 1. Latvian financial stress index and leverage from 1995-2011

Source: Bank of Latvia (2013); Central Statistical Bureau of Latvia (2013). 
sector stress have returned to a level close to their long-term values, yet the high provisions ratio, significant losses of the banking sector and shrinking loans still suggest that the stress level of the financial sector remains high.

From the graphical analysis, it was concluded that the correlation between financial stress index and the leverage is questionable. Given that financial market instability can cause a condition in which a firm's financial obligations are not met, or are honoured with difficulty, a financially distressed firm faces situations varying from non-payment to suppliers or preferred stockholders to bankruptcy declaration (e.g., Beaver, 1966; Dimitras et al., 1996).

Nevertheless, although the literature indicated mixed findings for the relationship between the degree of financial market instability and leverage, the current study expects a negative relationship.

Hypothesis 5: Financial market instability has negative relationship with leverage.

\section{Methodology}

In this study the authors used the Generalized Methods of Moments (GMM) to capture the dynamic nature of the capital structure. GMM estimation was formalized by L.P. Hansen (1982), and since has become one of the most widely used methods for estimation of models in economics and finance. GMM does not require complete knowledge of the distribution of the data; only specified moments derived from an underlying model are needed for GMM estimation. In some cases, in which the distribution of the data is known, GMM can be computed very easily. In models for which there are more moment conditions than model parameters, GMM estimation provides a straightforward way to test the specification of the proposed model. This is an important feature that is unique to GMM estimation (GMM).

The method requires that a certain number of moment conditions were specified for the model. These moment conditions are functions of the model parameters and the data, such that their expectation is zero at the true values of the parameters. The GMM method then minimizes a certain norm of sample averages of the moment conditions. The GMM estimators are known to be consistent, asymptotically normal, and efficient in the class of all estimators that don't use any extra information aside from that contained in the moment conditions.

The proposed General model is:

FLev $_{t}=\beta_{0}+\beta_{1}$ Flev $_{t-1}+\beta_{2}$ TNGB $_{t}+$ $\beta_{3} \operatorname{Prf}_{t}+\beta_{4} E V_{t}+\beta_{5} \mathrm{Grw}_{t}+\beta_{6} A s s_{t}+$ $\beta_{6} A s s_{t}+\beta_{6} F S_{t}+\varepsilon_{t}$

where, Lev $t_{t}$ - Financial leverage in time t; Lev ${ }_{t-1}$ - Lagged financial leverage in time $\mathrm{t}-1$; $T N G B_{t}$ - Tangibility in time t; $\operatorname{Prf}_{t}$ - Profitability in time $t ; E V_{t}$ - Earnings Volatility in time $\mathrm{t}$; $G r w_{t}$ - Sales growth in time t; $A s s_{t}-$ Assets growth in time t; $F S_{t}$ - Financial market instability in time $\mathrm{t} ; \varepsilon_{t}$ - Error.

\section{Empirical Results and Discussion}

Our econometric evidence confirms that the main independent variables affecting the leverage in Latvia are following: tangibility, profitability, assets growth and financial market instability determinant, which is the interbank market spread - the difference between 3 month RIGIBOR and EURIBOR (see formula 2). 
Model results

Table 2

\begin{tabular}{|c|c|c|c|c|}
\hline \multicolumn{5}{|l|}{ Residuals: } \\
\hline Min & $1 Q$ & Median & $3 Q$ & Max \\
\hline-0.23829 & -0.03909 & -0.01491 & 0.05570 & 0.18865 \\
\hline \multicolumn{5}{|l|}{ Coefficients: } \\
\hline & Estimate & Std. Error & $t$ value & $\operatorname{Pr}(>|t|)$ \\
\hline Prf & -6.329508 & 1.281097 & -4.941 & $0.00027^{* * *}$ \\
\hline Ass & 0.523013 & 0.019442 & 26.901 & $8.78 \mathrm{e}-13^{* * *}$ \\
\hline TNGB & -7.046605 & 0.440107 & -16.011 & $6.16 \mathrm{e}-10^{\star * *}$ \\
\hline FS & -0.013688 & 0.006658 & -2.056 & 0.06044 \\
\hline
\end{tabular}

Note: residual standard error: 0.1166 on 13 degrees of freedom; Multiple R-squared: 0.9966, Adjusted R-squared: 0.9955; F-statistic: 949.5 on 4 and 13 DF, p-value: $6.88 \mathrm{e}-16$.

$$
\begin{aligned}
& F L \text { e } v_{t}=\beta_{1} T N G B_{t}+\beta_{2} \operatorname{Prf}_{t}+ \\
& \beta_{3} A s S_{t}+\beta_{4} F S_{t}+\varepsilon_{t}
\end{aligned}
$$

Table 2 presents the estimated coefficients and their t-values along with p-values.

The coefficient of determination $R^{2}$ in current model (0.9966) indicates that a regression line fits the data well. To take account of the phenomenon of statistical shrinkage - the tendency of models to perform less well out of sample than in sample, the adjusted $R 2$ (0.9955) was calculated. The adjusted $R^{2}$ is a modification according to Theil of $R^{2}$ that adjusts for the number of explanatory terms in a model relative to the number of data points. Unlike $R^{2}$, the adjusted $R^{2}$ increases when a new explanatory is included only if the new explanatory improves the $R^{2}$ more than would be expected by chance. If a set of explanatory variables with a predetermined hierarchy of importance are introduced into a regression one at a time, with the adjusted $R^{2}$ computed each time, the level at which adjusted $R^{2}$ reaches a maximum, and decreases afterward, would be the regression with the ideal combination of having the best fit without excess/unnecessary terms. Adjusted $R^{2}$ does not have the same interpretation as $R^{2}$ - while $R^{2}$ is a measure of fit, adjusted $R^{2}$ is a comparative measure of suitability of alternative numbers of explanatories. High level of the adjusted $R^{2}$ proves the right choice of variable selection in this model.

An F-test is any statistical test in which the test statistic has an F-distribution under the null hypothesis. In current model, FStatistics prove that a high $R^{2}$ value is not accidental.

Significance of the model was confirmed by the test of residuals statistics,

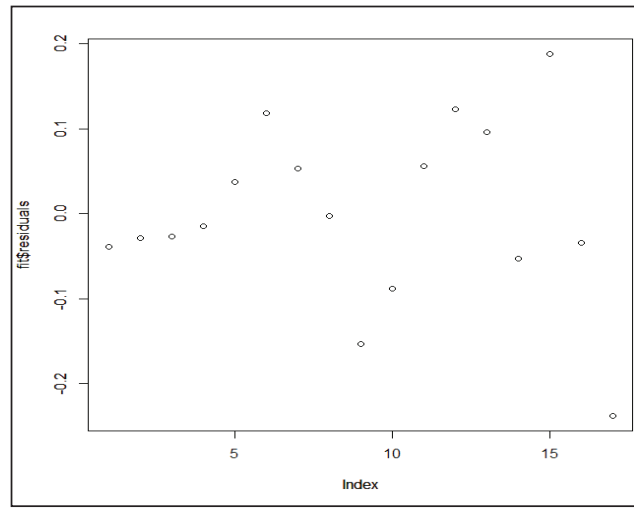

Fig. 2. The statistics of current model residual plot 
the difference between the sample and the estimated function value (Figure 2).

A residual plot is a graph that shows the residuals on the vertical axis and the independent variable on the horizontal axis. As the points in a residual plot are randomly dispersed around the horizontal axis, the current regression model is appropriate for the data.

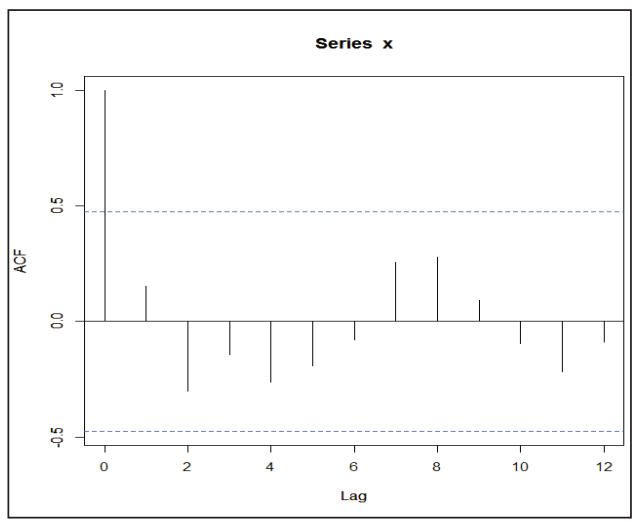

Fig. 3. Correlogram of the model

Autocovariance test (Figure 3) also proves the statistical significance of the current model.

\section{Conclusions}

Although our model is minimalistic, it could still analyse the main determinants affecting financial leverage of Latvia's nonfinancial companies taking into account financial market instability. The econometric evidence confirms that the main independent variables affecting the leverage in Latvia are tangibility, profitability, growth of assets and the difference between 3 month RIGIBOR and EURIBOR.

As the results reveal, tangibility is negatively correlated with leverage. It is statistically highly significant with a coefficient of -7.04 that proves our hypothesis 1. The negative relationship of tangibility with leverage confirms the Pecking-Order Hypothesis and is contrary to the Tradeoff theory of capital structure choice.

Profitability is negatively related with leverage. The coefficient (-6.32) is highly statistically significant and confirms the authors' hypothesis 2. Profitability, as espoused by the Pecking-Order Hypothesis, is negatively correlated with leverage, indicating that the growth of profitability made firms use internal financing instead of debt financing.

The asset growth variable, as the results reveal, is positively related to leverage and statistically highly significant that proves our hypothesis 4 . This result confirms the Pecking-Order theory that growing firms have greater need for funds and, therefore, can be expected to borrow more.

For examination of the separate effect of other independent variables not included in the current model, findings show a positive, highly statistically significant effect of lagged leverage (correlation coefficient 0.9569); negative effect of earnings volatility (correlation coefficient -0.33 ) proving hypothesis 3 and sales growth (correlation coefficient -0.4937).

The study results highlight that financial market instability, measured as the difference between 3 month RIGIBOR and EURIBOR, has a negative impact on leverage of the firm, indicating that firms shift from debt to equity market or to internal sources of financing once the financial market soundness is under the question, confirming hypothesis 5 .

The current study is not free from limitations. First, its current sample consists of only total statistics of companies by years; therefore, these findings may have limited 
generalizability. Future studies that replicate the current proposal, including panel data of non-financial firms listed on Nasdaq OMX Stock Exchange, may provide a more complete picture or add further dimensions to the current findings.

Second, the effects of leverage may be contingent on the size of firm, the length of business history, or the operational strategies and other determinants. Future research that examines those effects in a more specific context will add depth.

Third, regarding the financial market instability effect on leverage, due to a lack of supporting literature that directly suggests such an effect or relationship, a strong theoretical background would improve further researches significantly.

\section{References}

1. Baker, M., Wurgler, M. J. (2002). Marketing Timing and Capital Structure// Journal of Finance. Vol. 57., pp.1-32.

2. Barclay, M., Smith C. (1996). On Financial Architecture: Leverage, Maturity, and Priority // Journal of Applied Corporate Finance. Vol. 8, No. 4, pp. 4-17.

3. Beaver, W. H. (1966). Financial Ratios as Predictors of Failure // Journal of Accounting Research. Vol. 4 (1), pp. 71-111.

4. Bebczuk, R., Galindo, A. (2010). Corporate Leverage, the Cost of Capital, and the Financial Crisis in Latin America. Internet access: <http:// papers.ssrn.com/sol3/papers.cfm?abstract_ id=1577687> [accessed February 20, 2013].

5. Bernardo, A. E., Welch, I. (2012). Leverage and Pre-emptive Selling of Financial Institutions // J.Finan Intermediation. doi: 10.1016/j. jif.2012.09.004.

6. Bevan, A. A., Danbolt, J. (2002). Capital Structure and its Determinants in the United Kingdom-A Decompositional Analysis // Applied Financial Economics. Vol. 12(3), pp.159-170.

7. Bharath, S., Pasquariello P., Wu, G. (2007). Does Asymmetric Information Drive Capital Structure Decisions? // Review of Financial Studies. doi:10.1093/rfs/hhn07.

8. Campbell, K., Jerzemowska, M. (2001). Capital Structure Decisions Made by Companies in a Transitional Economy. In D. Zarzecki (Ed.). Financial management, objectives-organisationtools Warszawa: Fundacja Rozwoju Rachunkowo ci w Polsce, pp. 51-76.

9. Campello, M., Giambona, E. (2010). Asset Tangibility and Capital Structure. Internet access: <http://www.ebs.edu/fileadmin/redakteur/ funkt.dept.economics/Colloquium/100323
Giambona.pdf> [accessed February 21, 2013].

10. Central Statistical Bureau of Latvia data base. Internet access: <http://www.csb.gov.lv/statistikas-temas/uznemejdarbibas-finanses-galvenieraditaji-30309.html> [accessed February 24, 2013].

11. Crutchley, C., Hansen, R. (1989). A Test of the Agency Theory of Managerial Ownership, Corporate Leverage, and Corporate Dividends // Financial Management. Vol. 18, No. 4, pp. 36-46.

12. Dimitras, A. I., Zanakis, S. H., Zopounidis, C. (1996). A Survey of Business Failures with an Emphasis on Prediction Methods and Industrial Applications // European Journal of Operational Research. Vol. 90 (3), pp. 487-513.

13. Drobetz, W., Fix, R. (2003). What are the Determinants of the Capital Structure? Some Evidence for Switzerland.-Working Paper No. 4/03, University of Basel, WWZ/ Department of Finance.

14. Eurostat data base. Internet access: <http://epp. eurostat.ec.europa.eu/portal/page/portal/interest_rates/data/database $>$ [accessed February 9, 2013]

15. Fama, E., French, K. R. (2002). Testing Trade-off and Pecking Order Predictions about Dividends and Debt // Review of Financial Studies. Vol. 15, pp. 1-33.

16. Faulkender, M., Petersen M. A. (2006). Does the Source of Capital Affect Capital Structure? // Review of Financial Studies, Vol.19 (1), pp. 45-79. doi: 10.1093/rfs/hhj003.

17. Financial and Capital Market Commission data base. Internet access: <http://www.fktk.lv/lv/ statistika/kreditiestades/ceturksna_parskati/> [accessed February 9, 2013]

18. Friend, I., Lang, L. (1988). An Empirical Test of 
the Impact of Managerial Self-interest on Corporate Capital Structure // Journal of Finance. Vol. 43 (2), pp. 271-281.

19. Gajdka, J. (2002). Teorie struktury kapitału i ich aplikacja w warunkach polskich.1st ed.-Wydawnictwo Uniwersytetu Łódzkiego.

20. Gaud, P., Jani, E., Hoesli, M., Bender, A. (2005). The Capital Structure of Swiss Companies: an Empirical Analysis Using Dynamic Panel Data // European Financial Management. Vol. 11, No. 1, pp. 51-69.

21. Generalized Method of Moments. Internet access: $<$ http://faculty.washington.edu/ezivot/econ583/ gmm.pdf>, [accessed February 18, 2013].

22. Graham, J. R., Harvey, C. (2001). The Theory and Practice of Corporate Finance: Evidence from the Field // Journal of Financial Economics. Vol. 60, pp.187-243.

23. Hakkio, C. S., Keeton, W. R. (2009). Financial stress: What is it, how can it be measured, and why does it matter? Federal Reserve Bank of Kansas City, Economic Review, second quarter, pp. 5-50.

24. Hakkio, C., Keeton, W. (2009). Financial Stress: What Is It, How Can It Be Measured, and Why Does It Matter? // Economic Review. Federal Reserve Bank of Kansas City.

25. Hansen, L. P. (1982). Large Sample Properties of Generalized Methods of Moments Estimators // Econometrics. Vol. 50, pp. 1029-1054.

26. Hart, O., Moore, J. (1994). A Theory of Debt Based on the Inalienability of Human Capital // Quarterly Journal of Economics. Vol. 109 (4), pp.841-879.

27. Illing, M., Liu, Y. (2003). An Index of Financial Stress for Canada.-Working Paper no 2003-14, Bank of Canada.

28. Illing, M., Liu, Y. (2006). Measuring Financial Stress in a Developed Country: An Application to Canada // Journal of Financial Stability. No. 2, pp. 243-265.

29. Jensen, M., Meckling, W. (1976). Theory of the Firm Managerial Behaviour, Agency Costs and Ownership Structure // Journal of Financial Economics. Vol. 3(4), pp. 305-360.

30. Kale, J. R., Shahrur, H. (2007). Corporate Capital Structure and the Characteristics of Suppliers and Customers // Journal of Financial Economics. Vol. 83, pp. 321-365.

31. Lee, S., Koh, Y., Kang, K. H. (2010). Moderating Effect of Capital Intensity on the Relationship between Leverage and Financial Distress in the
U.S. Restaurant Industry // International Journal of Hospitality Management. Vol. 30, Issue 2, pp. 429-438. doi:10.1016/j.ijhm.2010.11.002.

32. Lemmon, M. L., Roberts M. R., Zender J. F. (2008a). Back to the Beginning: Persistence and the Cross-Section of Corporate Capital Structure// Journal of Finance. Vol. 63 (4), pp. 15751608.

33. Lemmon, M. L., Zender J. F. (2008b). Debt Capacity and Tests of Capital Structure Theories. -Working paper, University of Utah and University of Arizona.

34. Mackay, P., Phillips, G. G. (2005). How Does Industry Affect Financial Structure? // Review of Financial Studies. Vol. 18 (4), pp.1433-1466.

35. Ministry of the Finance of the Republic of Latvia. Internet access: <http://www.fm.gov.lv/lv/sadalas/eiro_ieviesana_latvija/mastrihtas_kriteriji/>, [accessed February 9, 2013].

36. Misina, M., Tkacz, G. (2009). Credit, Asset Prices, and Financial Stress // International Journal of Central Banking. Vol. 5(4), pp. 95-122.

37. Modigliani, F., Miller, M. H. (1958). The Cost of Capital, Corporate Finance and the Theory of Investment // American Economic Review. Vol. 48, pp. 261-297.

38. Myers, S. (1977). Determinants of Corporate Borrowing // Journal of Financial Economics. Vol. 5(2), pp. 147-175.

39. Myers, S. C. (1984). The Capital Structure Puzzle // Journal of Financial. Vol. 39, pp. 575-592.

40. Myers, S. C., Majluf, N. (1984). Corporate Financing and Investment Decisions when Firms Have Information that Investors Do Not Have// Journal of Financial Economics. Vol. 13, pp. $187-221$.

41. Ozkan, A. (2001). Determinants of Capital Structure and Adjustment to Long Run Target: Evidence from UK Company Panel Data // Journal of Business Finance \& Accounting. Vol. 28, No. 1 \& 2, pp. 175-198.

42. Rajan, R., Zingales, L. (1995). What do We Know about Capital Structure? Some Evidence from International Data // Journal of Finance. Vol. 50, pp. 1421-1460.

43. Shyam-Sunder, L., Myers S. C. (1999) Testing Static Tradeoff against Pecking Order Models of Capital Structure// Journal of Financial Economics, Vol.51, pp. 219-244.

44. Shleifer A., Vishny, R. W. (1992). Liquidation Values and Debt Capacity: A Market Equilibrium Approach // Journal of Finance 47 (4), 
pp. 1343-1366.

45. Siņenko, N., Titarenko, D. and Arins, M. (2012). Latvian Financial Stress Index.-Working paper, Bank of Latvia.

46. Stulz, R. (1990). Managerial Discretion and Optimal Financing Policies // Journal of Financial Economics. Vol. 26, pp. 3-27.

47. Titman, S., Wessels, R. (1988). The Determinants of Capital Structure Choice // Journal of Finance. Vol. 43, pp. 1-19.

48. Wald, J. K., Long M. S. (2007). The Effect of State Laws on Capital Structure // Journal of Financial Economics. Vol. 83, pp. 297-319.

49. Williamson, O. E. (1988). Corporate Finance and Corporate Governance // Journal of Finance. Vol. 43, pp. 567-592.

The paper submitted: April 22, 2013

Prepared for publication: June 1, 2013

Ramona RUPEIKA-APOGA, Elvira ZELGALVE

FINANSINIS SVERTAS IR FINANSU RINKOS NESTABILUMAS: LATVIJOS ATVEJIS

\section{S a n t r a u k}

Optimalios kapitalo struktūros nustatymas buvo ir yra iššūis visiems mokslininkams ir praktikams jau daugelị dešimtmečių. Viso to rezultatas - įvairios teorijos, kurios padeda kompanijoms suprasti, kaip suformuoti savo kapitalo struktūrą. Tačiau optimalios kapitalo struktūros tematika dar vis plačiai diskutuotina. Pastaraisiais metais ekonominè aplinka pasikeitė visame pasaulyje, o tai sukūrè naujus iššūkius i̇monèms pasirenkant optimalią išteklių struktūrą. Straipsniu buvo siekiama dinamine sąranka sujungti finansų rinkos nestabilumą ir įmonių finansus. Finansų rinkos nestabilumą gali apibūdinti finansinis stresas. Sunku apibrèžti finansinio streso sampratą; nèra aiškaus ar visuotinai pripažinto apibrèžimo, tačiau dauguma indeksų, kurie parodo finansinị stresą, gana dažnai naudojami moksliniuose tyrimuose.

Šio straipsno objektas yra nefinansinių i̇monių elgesys formuojant kapitalo struktūrą.

Šio tyrimo tikslas yra nustatyti ir išanalizuoti pagrindinius veiksnius, kurie turi įtakos Latvijos nefinansinių ịmonių finansiniam svertui, atsižvelgiant $i$ finansų rinkos nestabilumą.

Siekiant užsibrèžto tyrimo tikslo buvo sprendžiami šie uždaviniai:

1. ịvardinti pagrindines kapitalo struktūros teorijas;

2. nustatyti ir išanalizuoti pagrindinius veiksnius, kurie daro ịtaką finansiniam svertui, ypač pabrèžiant finansinị nestabilumą.
3. pasiūlyti modelį, kuris sujungia finansų rinkos nestabilumą ir i̇monių finansus Latvijoje;

4. remiantis tyrimo rezultatais padaryti išvadas bei pateikti rekomendacijas apie finansų rinkos nestabilumo ir i̇monių finansų koreliacijas.

Tyrimo metu naudoti šie metodai: literatūros apžvalga, kurioje atskleisti sunkumai su kuriais susiduria ịmonès renkantis optimalią kapitalo struktūrą; praktineje dalyje naudotas ekonometrinis (Generalized Methods of Moments - GMM) metodas, kurio metu buvo tiriami įmonių kapitalo struktūros pokyčiai 1995-2012 m. laikotarpiu.

Tyrimo metu naudoti duomenys paimti iš Latvijos Statistikos Departamento, Finansų ir Kapitalo Rinkos Komisijos, Latvijos Finansų Ministerijos, Latvijos Centrinio Banko ir Eurostat.

Tyrimo rezultatai parodè, kad finansų rinkos nestabilumas turi neigiamą poveikị i̇monių finansiniam svertui. Paaiškejo, kad ịmonès pereina nuo paskolų prie akcijų rinkos, kai tik finansų rinkos patikimumas yra abejotinas. Rezultatai taip pat patvirtina, kad materialumas neigiamai koreliuoja su finansiniu svertu, o tai prieštarauja „Trade-off” kapitalo pasirinkimo teorijai, tačiau gerai paaiškina „Pecking-Order” hipotezę. Pelningumas neigiamai koreliuoja su finansiniu svertu, o tai parodo, kad pelningumo augimas privertė įmones naudoti vidinị finansavimą, o ne skolintis. Turto augimo atveju gaunama priešinga situacija: įmonès augimo periode yra poreikis didesniam finansavimui, dèl to tikimasi daugiau skolintis. 